\title{
Marshallius bondari, a new species of Hylobiinae (Coleoptera, Curculionidae). ${ }^{1}$
}

\author{
Germano H. Rosado-Neto ${ }^{2}$
}

\section{ABSTRACT}

Marshallius bondari, a new species of Hylobiinae (Coleoptera, Curculionidae) is described from Nova Soure, Bahia, Brazil. Illustrations of the male and the female genitalia and a short bionomic information are given.

\section{INTRODUCTION}

I was recently asked by the "Centro de Identificação de Insetos Fitófagos, Departamento de Zoologia da Universidade Federal do Paraná, Curitiba, Brasil" to identify some specimens of curculionids found in a culture of cashew. In the sample there were some specimens of Marshallius anacardii Lima, 1979 and several specimens of an unknown species of the same genus. Later on, I received from Dr. Guilherme L. de C. Marback (Ministério da Agricultura, Salvador, Bahia) three more specimens of that species sent previously to the American Museum of Natural History, New York, returned without identification. After a close comparison with specimens preseverd in the collection of our Department, I concluded that they belong to a new species.

All the specimens were collected in Nova Soure, Bahia, damaging stems and branches of cashews (Anacardium occidentale L.) (Anacardiaceae).

\section{Marshallius bondari sp. $\mathbf{n}$.}

(Figs. 1-7)

TYPE MATERIAL: HOLOTYPE male, Brazil (Nova Soure, BA, 28. XI. 1987, A.L.M. Mesquita; 628/87). PARATYPES: 7 males and 3 females, with same label data as holotype; 1 male and 3 females, same locality as holotype, except "I/1988, S.W.P. Bispo; 651/88 n. 001". The types are deposited in the collection of Departamento de Zoologia, Universidade Federal do Paraná, Curitiba, Paraná, Brazil.

1 Contribuição n: 654 Departamento de Zoologia, UFPR.

2 Departamento de Zoologia - UFPR, Caixa Postal 3034; 80001, Curitiba - PR, Brasil. Bolsista do CNPq. 
HOLOTYPE male (Figs. 1-2). LENGTH (pronotum and elytra): 14.83 mm. WIDTH: $6.50 \mathrm{~mm}$. Robust, 2.3 times as long as humeral width; integument black with unctuous shine; densely clothed with short dark brown scales, with spots of yellow and black scales on pronotum and elytra; yellow scales ventrally; head and base of rostrum covered with smaller, sparse and ferruginous scales. ROSTRUM slender, weakly curved in profile; 5.2 times longer $(4.75 \mathrm{~mm})$ than wide at base $(0.92 \mathrm{~mm})$; slightly longer than pronotal length $(4.33 \mathrm{~mm})$; basal half with dense coarse rugose punctures; with a narrow and shortened dorsal median carina, narrower before middle. ANTENNAE with submedian insertion, scape $(1.80 \mathrm{~mm})$ claviform, not reaching the eyes, shorter than funicle $(2.70 \mathrm{~mm})$; this with segments 1 to 4 slightly elongate, the first two subequal and more elongate; segments 5 to 7 as long as wide; club short oval, as long as funicular segments 5 to 7 together. EYES subreniform, weakly convex, narrowly separated by a distance 0.15 times the width of rostrum at base. PROTHORAX transverse, as long as wide; greatest width near the middle; sides rounded from base to middle, there narrowed and strongly constricted at apex; postocular lobes not prominent; disc coarsely and deeply punctate, with subcarinate impunctate median line not reaching the base; margins of punctures raised, producing a shine granulate appearance; two transversal spots of yellow scales a little before middle, extending laterally to base; anteriorly at sides with more sparse and yellow scales; the base of disc with 2 semicircular black spots; hind margin bisinuate and narrowly margined. SCUTELLUM small, subtriangular, densely clothed with yellow scales. ELYTRA elongate, 1.7 times longer $(11.00 \mathrm{~mm})$ than humeral width $(6.50 \mathrm{~mm})$ and 2.5 times longer than pronotum; weakly convex; anterior margili bisinuate; humeri rounded; striae strongly impressed, with large deep punctures, becoming smaller towards declivity and apex; margins of punctures raised, producing a trifle granulate appearance; interstriae not elevated, subequal to or slightly wider than striae, with sparse granuliform punctures; sides subparallel, gradually narrowed after the posterior declivity; this moderately abrupt; apices conjointly rounded; vestiture tomentose, with predominance of dark brown scales, and maculae of yellow and black scales; each elytron with a large oblique transverse and irregular band of yellow scales on apical half; a small yellow spot on base of interstriae 5 and 6; another behind and below humeri; basal margin at the sides of scutellum with a short narrow transverse black spot reaching the interstria 4; dorsally before middle with two small irregular spots on interstriae 2 and 6 respectively; posteriorly adjoining the yellow transversal band, just in front and behind it, with a more larger irregular black macula on interstriae 2 to 4; laterally and apicaly with other small irregular spots; each puncture of elytral striae bearing a small elongate greyish scale. LEGS with femora (4.92:4.83:6.33 mm) claviform, weakly rugose, sparsely clothed with brownish or pale scales; armed with large acute tooth; fore and mid subequal; hind femur longer, reaching the elytral apex. Tibiae (4.42:4.08:5.00 mm) slightly rugose, with coarse subconfluent punctures, 
not sulcate; inner margin not toothed, feebly carinate, sinuate; externally weakly curved; premucro acute; unci strongly acute, oblique; outer apical comb of hind tibia ascendent, with a single row of dark ferruginous to black bristles. Tarsi with segment 1 as long as segments 2 and 3 together; segment 4 slightly longer than segment 1; tarsal claws free, simple, divergent. VENTER with prosternum, mesosternum, lateral areas of metasternum, abdominal sternum 1 behind coxae and flanks of sterna 3 and 4 with more elongate yellow scales. Prosternum with an anterior strong transversal groove interrupted by a tuberculiform protuberance in the middle; metasternum smooth medially, with sparse coarse punctures laterally. Abdominal sternum 1 behind coxae as long as sternum 2, anterior margin strongly rimmed, with a weak depression in the middle near posterior margin; this bisinuate; sternum 2 as long as sterna 3 and 4 together; the three truncate at posterior margin; sternum 5 with a median depression and strongly lowered at sides, shorter than 3 and 4 together. GENITALIA as in figs. 3 and 4.

FEMALE. Same as holotype except as follows: more robust; antennae inserted little before middle; abdominal sterna 1 and 5 without median depression; genitalia as in figs. 5, 6 and 7 .

PARATYPES. Similar to the holotype except for the black spots on elytra which may have variation in size; other very small and irregular black spots may be present. MALE: length, $13.17-15.33 \mathrm{~mm}(\overline{\mathrm{x}}=$ $14.77 \mathrm{~mm}, \mathrm{n}=8)$; width, $5.83-6.67 \mathrm{~mm}(\overline{\mathrm{x}}=6.48 \mathrm{~mm}, \mathrm{n}=8)$. FEMALE: length, $14.67-17.17 \mathrm{~mm}(\overrightarrow{\mathrm{x}}=16.16 \mathrm{~mm}, \mathrm{n}=6)$; width, $6.00-7.50 \mathrm{~mm}(\overline{\mathrm{x}}=6.91 \mathrm{~mm}, \mathrm{n}=6)$.

NON TYPES. Three more specimens were examined: one male and 2 females labelled "Nova Soure, BA, Faz. Cajuba 20/08/80, sobre cajueiro Edgard col. Marback prep." which were returned to Dr. Marback (Ministério da Agricultura, Salvador, Bahia). These are included here to present all available data.

SPECIFIC EPITHET. The name of this species commemorates the 30 years of Gregorio Bondar's death (1881 - 1959) and his contribution to the knowledge of Brazilian weevils.

DISTRIBUTION. Known only from the type series: Brazil, Nova Soure, Bahia.

DISCUSSION. Closely related to $M$. anacardii Lima. 1979 by its distribution, host plant and especially by the vestiture of pronotum and elytra. Marshallius bondari sp. n. is distinguished from $M$. anacardii 
by its robust body size; pronotal deep punctures (sparse and granulate in $M$. anacardii); integument black or dark brown (brown reddish in $M$. anacardii), and by the anterior tuberculiform protuberance of the prosternum between the coxae (absent in $M$. anacardii).

BIONOMIC NOTES. Guilherme L. de C. Marback (in litt.) informed me that the female of $M$. bondari deposits the eggs near collum of the host plant. After emergence, the young larva burrows into the tissues forming the galeries towards the roots. During growth, the larva reaches the higher parts and the branches of the plant. The younger plants have theirs roots destroyed by the insects, sometimes causing their death. The immature forms are found more frequently from August to October.

ACKNOWLEDGEMENT. I am indebted to the following persons: Dr. Guilherme L. de C. Marback, Ministério da Agricultura, Salvador, Bahia, who furnished biological data and the loan of 3 specimens; Dr. Pedrito Silva, CEPLAC, Salvador, Bahia, who called my attention to $M$. bondari and responsible for my first contact with Dr. Marback; Dr. Albino M. Sakakibara and Pe. Jesus S. Moure, Departamento de Zoologia, Universidade Federal do Paraná for the photographs and for the reviewing the manuscript respectively.
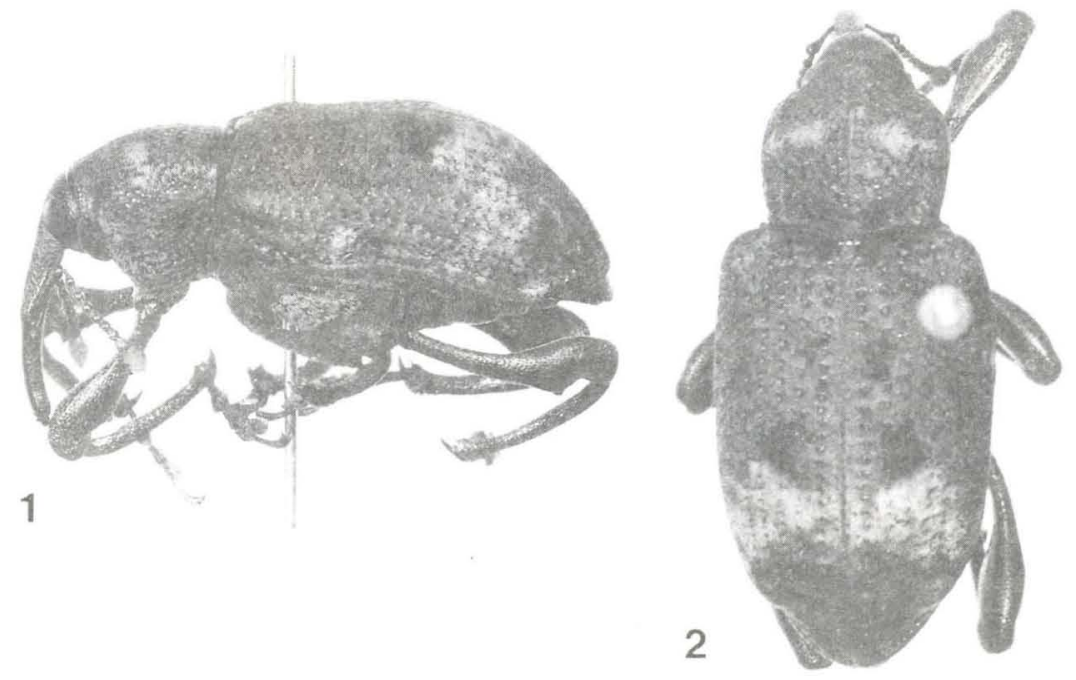

FIGS. 1 - 2: Marshallius bondari sp. n. (Holotype male). 1, lateral; 2, dorsal. 


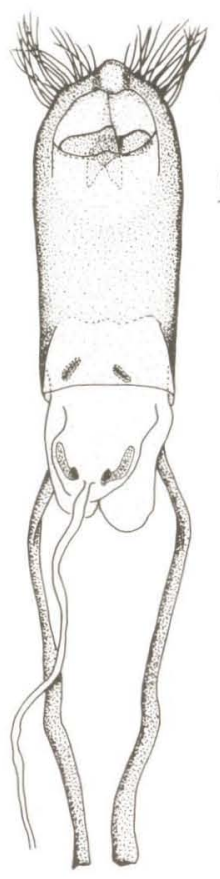

3

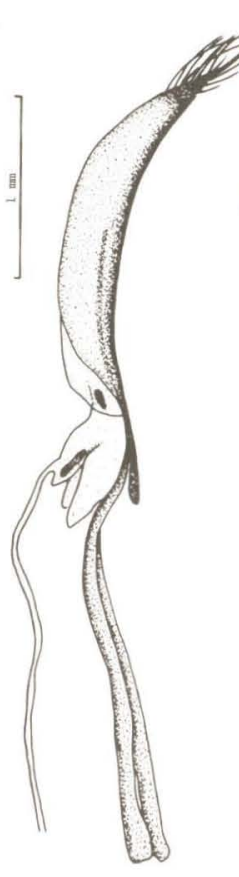

4

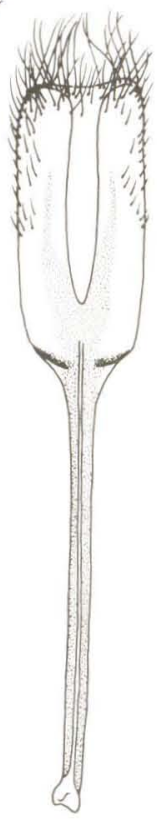

5

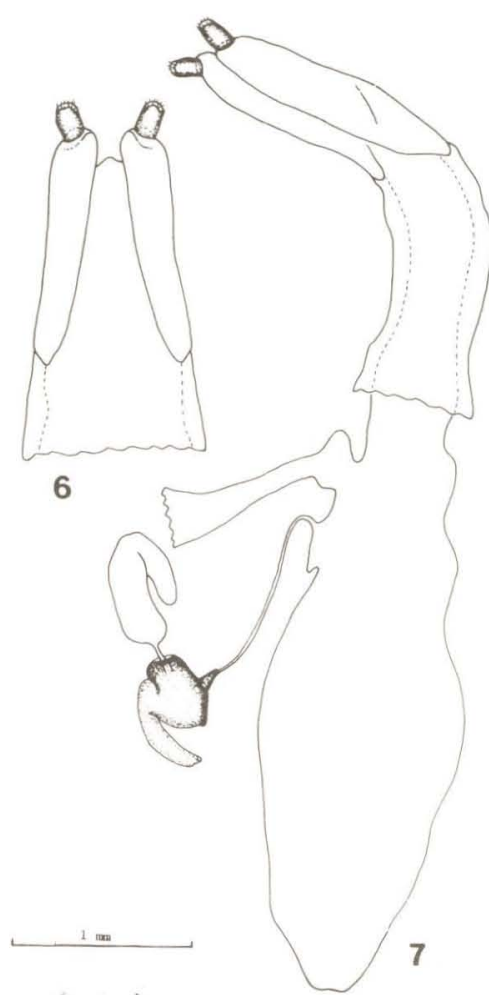

FIGS. 3 - 7: Marshallius bondari sp. n. 3, aedeagus, dorsal; 4, same, lateral (Holotype male); 5, sternite -8 , ventral; 6 , hemisternite and stylus, ventral; 7 , genitalia, lateral view: ovipositor, vagina, oviduct, bursa copulatrix, spermathecal duct, spermatheca and spermathecal gland.

\section{REFERENCES}

LIMA,V.C.A. 1979. Contribuição ao estudo de Marshallius anacardii $\mathrm{sp} . \mathrm{n}$. praga do cajueiro em Pernambuco (Coleoptera, Curculionidae). An. Univ. Fed. Rural PE, Recife, 4: 115-148. 